\title{
In situ FT-IR spectroscopic studies on the mechanism of the catalytic oxidation of carbon monoxide over supported cobalt catalysts
}

\author{
Chen-Bin Wang, ${ }^{\mathrm{a}, *}$, Chih-Wei Tang ${ }^{\mathrm{a}, \mathrm{b}}$, Hsin-Chi Tsai ${ }^{\mathrm{a}, \mathrm{b}}$, Ming-Chih Kuo ${ }^{\mathrm{b}}$, and Shu-Hua Chien ${ }^{\mathrm{b}, \mathrm{c}}$ \\ ${ }^{a}$ Department of Applied Chemistry, Chung Cheng Institute of Technology, National Defense University, Tahsi, Taoyuan, Taiwan 33509, Republic of \\ China \\ ${ }^{\mathrm{b}}$ Institute of Chemistry, Academia Sinica, Taipei, Taiwan 11529, Republic of China \\ ${ }^{\mathrm{c}}$ Department of Chemistry, National Taiwan University, Taipei, Taiwan 10764, Republic of China
}

Received 15 September 2005 Accepted 25 November 2005

\begin{abstract}
Three types of supported cobalt catalysts ( $5 \%$ as metal Co loading on $\mathrm{SiO}_{2}, \mathrm{Al}_{2} \mathrm{O}_{3}$ and $\mathrm{TiO}_{2}$ ) were prepared by incipient wetness impregnation with aqueous $\mathrm{Co}\left(\mathrm{NO}_{3}\right)_{2} \cdot 6 \mathrm{H}_{2} \mathrm{O}$ solution. Then, all catalysts were calcined in air at $400{ }^{\circ} \mathrm{C}$ (assigned as $5 \mathrm{Co} / \mathrm{Si} \mathrm{C} 400$, $5 \mathrm{Co} / \mathrm{Al} \mathrm{C400}$ and $5 \mathrm{Co} / \mathrm{Ti} \mathrm{C400).} \mathrm{Their} \mathrm{catalytic} \mathrm{activities} \mathrm{towards} \mathrm{the} \mathrm{CO}$ oxidation were studied in a continuous flow microreactor. Adsorption of carbon monoxide $(\mathrm{CO})$ and the co-adsorption of $\mathrm{CO} / \mathrm{O}_{2}$ over cobalt oxide were further tested under in situ FT-IR. The results showed that both $5 \mathrm{Co} / \mathrm{Si} \mathrm{C} 400$ and $5 \mathrm{Co} / \mathrm{Al} \mathrm{C} 400$ had higher activity than $5 \mathrm{Co} / \mathrm{Ti} \mathrm{C} 400$. The $\mathrm{T}_{50}(50 \%$ conversion) for both $5 \mathrm{Co} / \mathrm{Si} \mathrm{C400} \mathrm{and} 5 \mathrm{Co} / \mathrm{Al} \mathrm{C400} \mathrm{was} \mathrm{reached} \mathrm{at} \mathrm{temperatures} \mathrm{as} \mathrm{low} \mathrm{as} \mathrm{ambient} \mathrm{temperature.} \mathrm{According} \mathrm{to} \mathrm{the}$ in situ FT-IR analysis, the variation in oxidation of $\mathrm{CO}$ was interpreted with different mechanisms, i.e., the reaction between adsorbed $\mathrm{CO}$ and lattice oxygen of cobalt oxide, and part of $\mathrm{CO}_{2}$ formation via carbonates on $5 \mathrm{Co} / \mathrm{Si} \mathrm{C} 400$; both types of carbonates are formed on $5 \mathrm{Co} / \mathrm{Al} \mathrm{C400}$ to promote the $\mathrm{CO}$ oxidation; while both strong adsorption of $\mathrm{CO}$ on $\mathrm{TiO}_{2}$ and $\mathrm{CO}_{2}$ on cobalt oxide for $5 \mathrm{Co} / \mathrm{Ti} \mathrm{C} 400$ leads to affect the activity.
\end{abstract}

KEY WORDS: cobalt oxide; FT-IR; CO oxidation; adsorption.

\section{Introduction}

There are several reports describing the use of noble metals $(\mathrm{Pt}, \mathrm{Pd})$ for $\mathrm{CO}$ oxidation [1-7]. However, the high cost of noble metals and their sensitivity to sulfur poisoning have stimulated the search for substitute catalysts. Avoid the price and limited availability of previous metals, considerable attention has been paid to various transition metal oxides and mixed metal oxides. Owing to the importance of cobalt oxide as a catalyst for complete oxidation [8], cobalt oxide is one of the versatile materials among the transition metal oxides. In recent years, the research on $\mathrm{CO}$ oxidation is flourishing in the use of catalysts which contain bulk and supported metal oxides [9-15]. Our previous studies on bulk cobalt oxide [16-18] indicate that the relative activity decreased significantly with the oxidation state of cobalt and increased with the surface area of cobalt oxide. Loading a catalyst on high surface area support can modify the activity. Therefore, three kinds of supports $\left(\mathrm{SiO}_{2} \mathrm{Al}_{2} \mathrm{O}_{3}\right.$ and $\mathrm{TiO}_{2}$ ) are chose to detail studies of the catalytic oxidation of $\mathrm{CO}$ over supported cobalt catalysts.

The catalytic oxidation of $\mathrm{CO}$ over transition metal oxides is known to be accompanied by the formation of surface carbonate complexes, then interaction with the surface oxygen to evolve $\mathrm{CO}_{2}$. Therefore, surface carbonates are regarded as intermediates $[19,20]$. However, others suggest that the high thermal stability of surface

\footnotetext{
* To whom correspondence should be addressed.
}

E-mail: chenbin@ccit.edu.tw carbonates can deactivate the catalyst [21,22], thus raising doubt about their role as intermediates. In order to understand the relationship of formation of various surface species, in this study, in situ FT-IR has been used to demonstrate how $\mathrm{CO}$ reacts on the surface of supported cobalt catalysts.

\section{Experimental}

\subsection{Sample preparation}

Supported cobalt catalysts $(5 \%$ as metal Co) were prepared by incipient wetness impregnating the supports $\left[\left(\mathrm{Al}_{2} \mathrm{O}_{3}\left(\right.\right.\right.$ Merck, $\left.150 \mathrm{~m}^{2} \mathrm{~g}^{-1}\right), \mathrm{SiO}_{2}$ (Aerosil, $200 \mathrm{~m}^{2} \mathrm{~g}^{-1}$ ) and $\mathrm{TiO}_{2}$ (Degussa $\mathrm{P} 25,55 \mathrm{~m}^{2} \mathrm{~g}^{-1}$ )] with cobalt nitrate solutions. Then, samples were dried at $110{ }^{\circ} \mathrm{C}$ and calcined in air (represented as $T_{\mathrm{C}}$ ) at $400{ }^{\circ} \mathrm{C}$ for $4 \mathrm{~h}$, hereafter named $5 \mathrm{Co} / \mathrm{Si} \mathrm{C} 400,5 \mathrm{Co} / \mathrm{Al} \mathrm{C400} \mathrm{and} 5 \mathrm{Co} / \mathrm{Ti}$ C400, respectively.

\subsection{Activity test}

The catalytic activity of prepared samples towards $\mathrm{CO}$ oxidation was carried out in a continuous flow

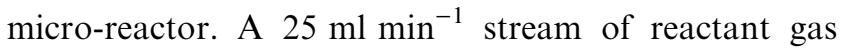
(mixed $10 \% \mathrm{O}_{2} / \mathrm{He}$ with $4 \% \mathrm{CO} / \mathrm{He}$ ) was catalyzed with $40 \mathrm{mg}$ of freshly prepared catalysts. The reactor temperature was raised stepwise from room temperature to $300{ }^{\circ} \mathrm{C}$. The reaction products were analyzed on-line using a Varian 3700 gas chromatograph with a 
carbosphere column. Before reaction, the catalyst was activated in flowing $10 \% \mathrm{O}_{2} / \mathrm{He}$ at $500{ }^{\circ} \mathrm{C}$ for $3 \mathrm{~h}$.

\subsection{In situ FT-IR study}

A self-supporting wafer $(1.3 \mathrm{~cm}$ diameter $)$ was prepared by compressing an $80 \mathrm{mg}$ sample and was mounted in a self-designed high temperature IR quartz cell with a $\mathrm{KBr}$ window. One set of stainless steel gas lines was built and connected to the cell that allowed in situ measurement of the spectra of $\mathrm{CO}$ and $\mathrm{CO} / \mathrm{O}_{2}$ probe gases. Prior to adsorption of the probes, the wafer was first pre-treated in vacuum $\left(<10^{-4}\right.$ torr $)$ at $500{ }^{\circ} \mathrm{C}$ for $30 \mathrm{~min}$ and then cooled to the desired temperature. At each temperature, the background spectrum was recorded and was subtracted from the sample spectrum that was obtained at the same temperature.

\section{Results and discussion}

\subsection{Catalytic activities towards the $\mathrm{CO}$ oxidation}

The catalytic oxidation of $\mathrm{CO}$ by $\mathrm{O}_{2}$ over supported cobalt catalysts is investigated at temperatures within the range of $0-300{ }^{\circ} \mathrm{C}$. The results are presented in figure 1 . The light-off temperature, denoted $T_{50}$, is here defined as the temperature where the conversion of $\mathrm{CO}$ reaches $50 \%$.

The better active catalysts are achieved over $5 \mathrm{Co} / \mathrm{Si}$ $\mathrm{C} 400$ and $5 \mathrm{Co} / \mathrm{Al} \mathrm{C} 400$, where $T_{50}$ are reached at temperatures as low as ambient temperature. That is lower than the noble metals $(\mathrm{Pt}, \mathrm{Pd})$ for $\mathrm{CO}$ oxidation [1-7]. At lower temperature, the activity increases with the temperature for both catalysts. However, when the temperature rose above $50{ }^{\circ} \mathrm{C}$, the $5 \mathrm{Co} / \mathrm{Si} \mathrm{C} 400$ catalyst lost its activity and then, the activity recovered as the temperature rises to $100{ }^{\circ} \mathrm{C}$. From TPO experiments, Jansson et al. [22] suggests that the presence of carbonates and surface carbon can deactivate the catalyst. This phenomenon can be eliminated by the regeneration of the deactivated catalyst in $10 \% \mathrm{O}_{2} / \mathrm{Ar}$ atmosphere. In the isotope study, Jansson [14] also confirms that the gas phase $\mathrm{CO}_{2}$ can react with the oxide surface to form a carbonate species. Konova et al. [23] suggests that the deactivation of a gold catalyst for $\mathrm{CO}$ oxidation is the capability to adsorb $\mathrm{CO}$ and accumulate it as carbonate. The deactivation found over $5 \mathrm{Co} / \mathrm{Si} \mathrm{C} 400$ in the range of $50-100{ }^{\circ} \mathrm{C}$ may therefore be attributed to the coverage of carbonates on catalyst surface. The carbonates may desorb as $\mathrm{CO}_{2}$ again when the temperature rise to $100{ }^{\circ} \mathrm{C}$. Consider the relationship of deactivation and surface area of the catalysts (i.e., $102 \mathrm{~m}^{2} \mathrm{~g}^{-1}$ for $5 \mathrm{Co} / \mathrm{Al}$ $\mathrm{C} 400,186 \mathrm{~m}^{2} \mathrm{~g}^{-1}$ for $\left.5 \mathrm{Co} / \mathrm{Si} \mathrm{C} 400\right)$, the high surface area of $5 \mathrm{Co} / \mathrm{Si} \mathrm{C} 400$ exhibits progressive deactivation with temperatures, while the $5 \mathrm{Co} / \mathrm{Al} \mathrm{C} 400$ exhibits progressive increase of activity with temperature. Maybe, the increase in surface carbonates coverage on

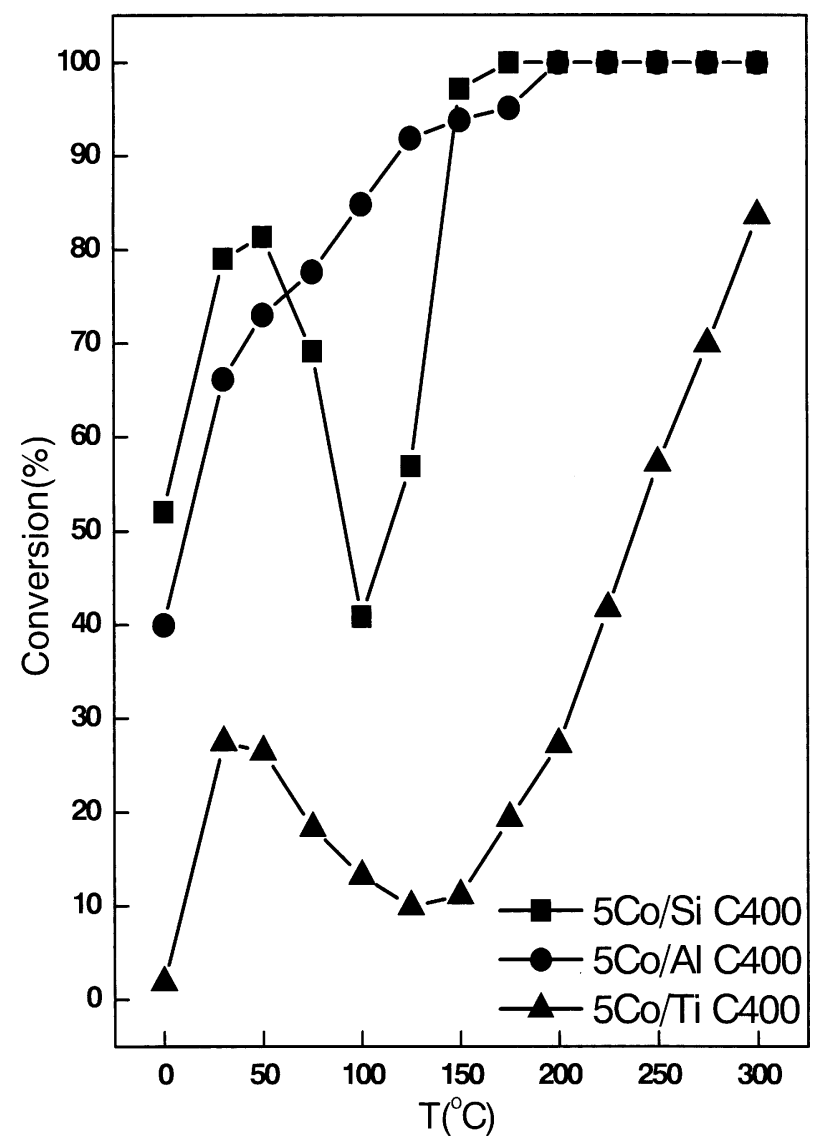

Figure 1. Conversion profiles for $\mathrm{CO}$ oxidation over supported cobalt

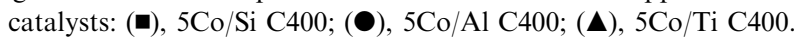

$5 \mathrm{Co} / \mathrm{Si} \mathrm{C} 400$ is accompanied by the blocking of the active sites to deactivate the catalyst. On the $5 \mathrm{Co} / \mathrm{Al}$ $\mathrm{C} 400$ catalyst, the cycle of $\mathrm{CO}_{2}$ evolution (activation) and re-adsorption (deactivation) may proceed in the range of $50-100{ }^{\circ} \mathrm{C}$. Further experiments must be explored with in situ FT-IR to elucidate the difference.

The lower surface area of $5 \mathrm{Co} / \mathrm{Ti} \mathrm{C} 400\left(43 \mathrm{~m}^{2} \mathrm{~g}^{-1}\right)$ exhibits lower activity than both $5 \mathrm{Co} / \mathrm{Al} \mathrm{C} 400$ and $5 \mathrm{Co} /$ Si C400 catalysts. Apparently, the variation of $T_{50}$ with the supported cobalt catalysts suggests that the kinds of support play an important role on their activity towards CO oxidation.

\subsection{In situ FTIR study}

We have performed in situ measurements of infrared spectra of $\mathrm{CO}$ and $\mathrm{CO} / \mathrm{O}_{2}$ adsorption on the surface of supported cobalt catalysts. Figures $2-4$ show the FT-IR spectrum of the $5 \mathrm{Co} / \mathrm{Si} \mathrm{C} 400,5 \mathrm{Co} / \mathrm{Al} \mathrm{C} 400$ and $5 \mathrm{Co} / \mathrm{Ti}$ C400 samples for $\mathrm{CO}$ adsorbed under a 0.5 torr $\mathrm{CO}$ pressure and different temperatures. The spectra of $5 \mathrm{Co} /$ Si C400 (figure 2) contained bands at 2349, 2166, 2143, 1610 and $1395 \mathrm{~cm}^{-1}$ between ambient temperature and $300{ }^{\circ} \mathrm{C}$. These can be assigned to gaseous $\mathrm{CO}_{2}$ $\left(2349 \mathrm{~cm}^{-1}\right)$ and CO $\left(2143 \mathrm{~cm}^{-1}\right)$, weakly linear adsorbed $\mathrm{CO}$ on cobalt oxide $\left(2166 \mathrm{~cm}^{-1}\right.$, which is desorbed 


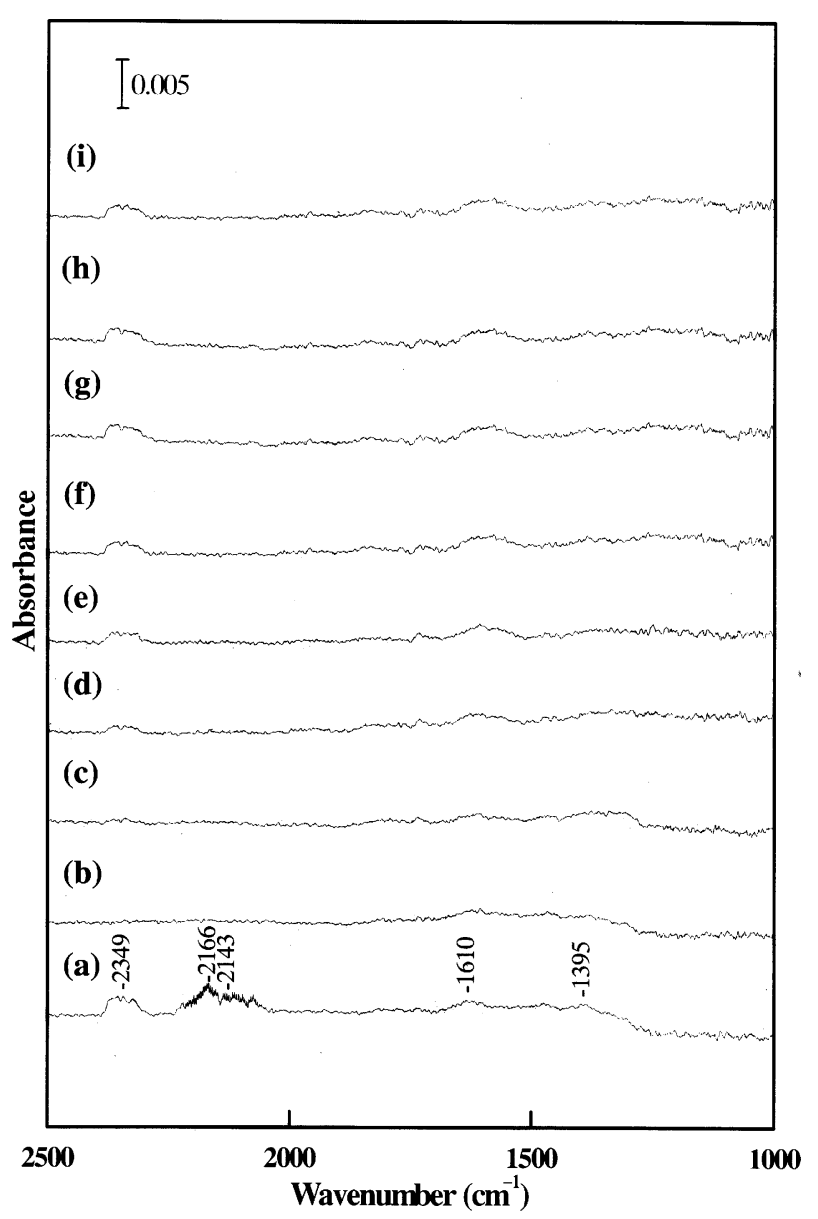

Figure 2. In situ FT-IR spectra of $5 \mathrm{Co} / \mathrm{Si} \mathrm{C} 400$ sample for 0.5 torr $\mathrm{CO}$ adsorbed at various temperatures: (a) R. T.; (b) evacuation; (c) $50{ }^{\circ} \mathrm{C}$; (d) $100{ }^{\circ} \mathrm{C}$; (e) $150{ }^{\circ} \mathrm{C}$; (f) $200{ }^{\circ} \mathrm{C}$; (g) $250{ }^{\circ} \mathrm{C}$; (h) $300{ }^{\circ} \mathrm{C}$; (i) cooling to R. T.

after evacuation [figure 2(b)]) [10] and carbonates formed on cobalt oxide surface $\left(1610\right.$ and $\left.1395 \mathrm{~cm}^{-1}\right)$, respectively. The formation of $\mathrm{CO}_{2}$ under room temperature simultaneous with the admission of 0.5 torr $\mathrm{CO}$ (figure 2(a)) indicates that the activity comes from the adsorbed $\mathrm{CO}$ and lattice oxygen of cobalt oxide.

$$
*-\mathrm{CO}+*-\mathrm{O}_{\mathrm{L}} \rightarrow \mathrm{CO}_{2}+*+{ }_{\mathrm{L}}
$$

where $*$ denotes an adsorption site on cobalt oxide surface, $\mathrm{O}_{\mathrm{L}}$ represents lattice oxygen of cobalt oxide, ${ }^{*} \mathrm{~L}$ is the escaping lattice oxygen resulted vacancy. Also, some of the adsorbed $\mathrm{CO}$ might migrate to form stable surface carbonates which remain present after evacuation (figure 2(b)). The effect of rising the temperature up to $300{ }^{\circ} \mathrm{C}$ for the surface carbonates has been studied (figure 2(c)-(h)). It is worthwhile notice that both the intensity of gaseous $\mathrm{CO}_{2}$ and carbonates increases with the temperature. Until the temperature reaches $300{ }^{\circ} \mathrm{C}$ (figure 2(h)), their intensities are constant. On FT-IR study for $\mathrm{CO}$ oxidation on cobalt oxides at $80 \mathrm{~K}$, Lokhov et al. [24] suggests that the re-adsorption of $\mathrm{CO}_{2}$ leads to the formation of stable carbonate complexes.

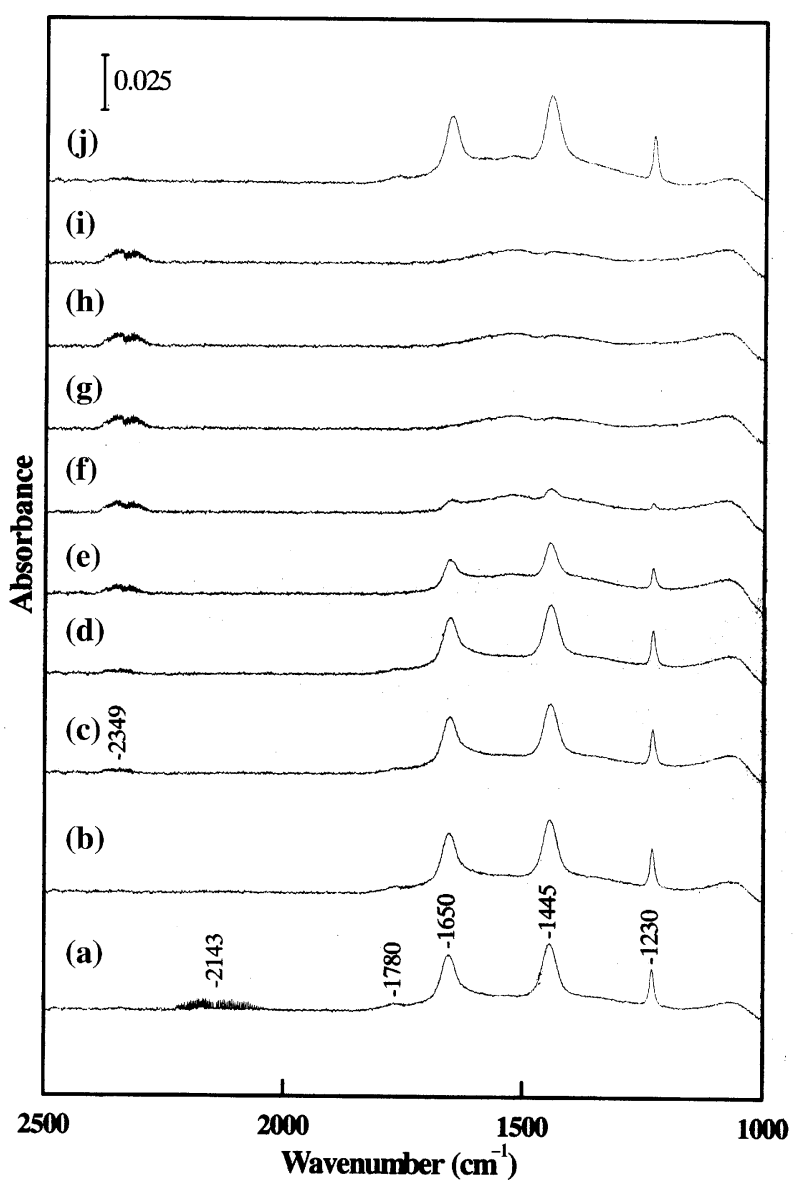

Figure 3. In situ FT-IR spectra of $5 \mathrm{Co} / \mathrm{Al} \mathrm{C} 400$ sample for 0.5 torr $\mathrm{CO}$ adsorbed at various temperatures: (a) R. T.; (b) evacuation; (c) $50{ }^{\circ} \mathrm{C}$; (d) $75{ }^{\circ} \mathrm{C}$; (e) $100{ }^{\circ} \mathrm{C}$; (f) $150{ }^{\circ} \mathrm{C}$; (g) $200{ }^{\circ} \mathrm{C}$; (h) $250{ }^{\circ} \mathrm{C}$; (i) $300{ }^{\circ} \mathrm{C}$; (j) cooling to R. T.

Also, in Finocchio et al. [25] experimental finds that a strong adsorption is produced after exposed 50 torr $\mathrm{CO}_{2}$ on $\mathrm{Co}_{3} \mathrm{O}_{4}$ at RT. The observed tendency may therefore result from part of $\mathrm{CO}_{2}$ formation via carbonate and part of carbonates is formed via gaseous $\mathrm{CO}_{2}$ re-adsorption. The dynamic equilibrium also exists after the temperature cooling to room temperature.

$$
\begin{aligned}
& *-\text { carbonate } \rightarrow \mathrm{CO}_{2}+* \\
& \mathrm{CO}_{2}+* \rightarrow *-\text { carbonate }
\end{aligned}
$$

The spectra of $5 \mathrm{Co} / \mathrm{Al} \mathrm{C400} \mathrm{(figure} \mathrm{3)} \mathrm{contained}$ bands at 2143, 1780, 1650, 1445 and $1230 \mathrm{~cm}^{-1}$ between ambient temperature and $300{ }^{\circ} \mathrm{C}$. Which assigned to gaseous CO $\left(2143 \mathrm{~cm}^{-1}\right)$, carbonate formed via the interface oxygen (assigned as $\mathrm{O}_{\mathrm{I}}$ ) and cobalt oxide $\left(1780 \mathrm{~cm}^{-1}\right)$, and other carbonates formed on cobalt oxide surface $\left(1650,1445\right.$ and $\left.1230 \mathrm{~cm}^{-1}\right)$, temporarily. Excluding gaseous $\mathrm{CO}$ and carbonates, no adsorbed $\mathrm{CO}$ and gaseous $\mathrm{CO}_{2}$ are observed (figure 3(a)) under room temperature. Meanwhile, two types of carbonates can be 


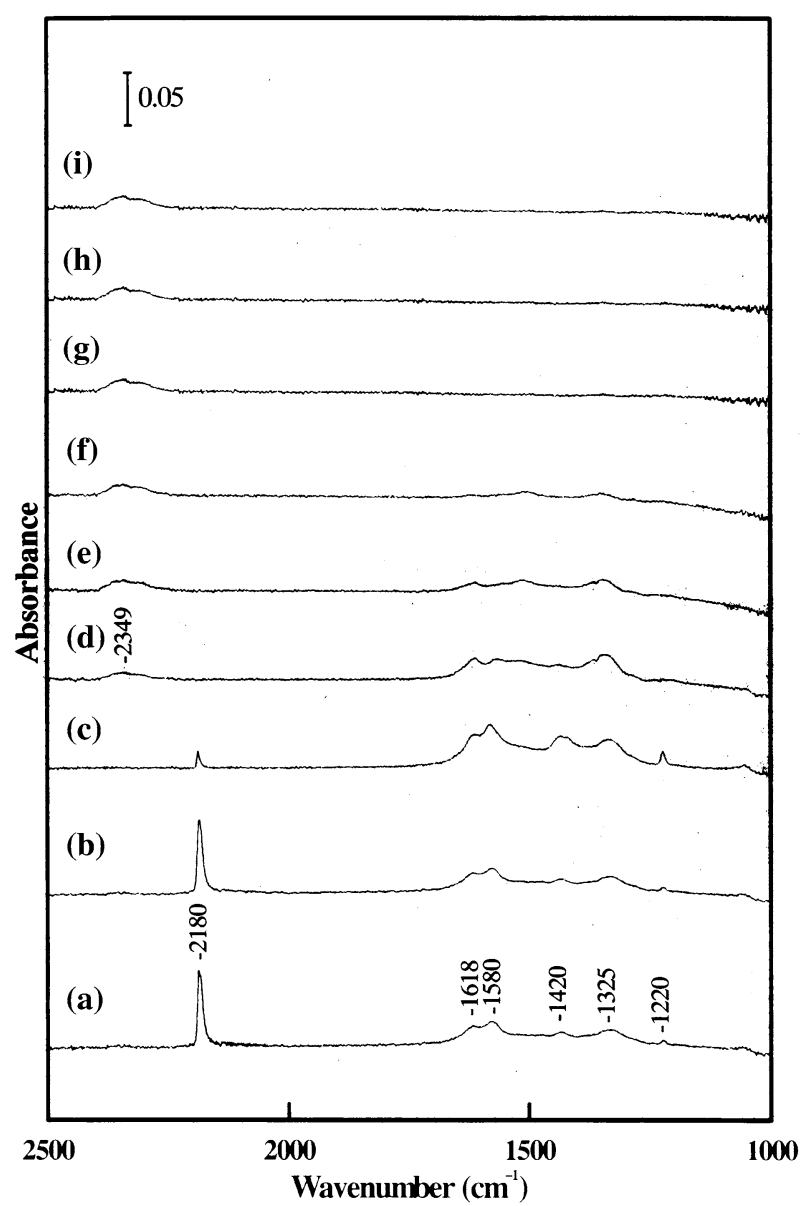

Figure 4. In situ FT-IR spectra of $5 \mathrm{Co} / \mathrm{Ti} \mathrm{C} 400$ sample for 0.5 torr $\mathrm{CO}$ adsorbed at various temperatures: (a) R. T.; (b) evacuation; (c) $50{ }^{\circ} \mathrm{C}$; (d) $100{ }^{\circ} \mathrm{C}$; (e) $150{ }^{\circ} \mathrm{C}$; (f) $200{ }^{\circ} \mathrm{C}$; (g) $250{ }^{\circ} \mathrm{C}$; (h) $300{ }^{\circ} \mathrm{C}$; (i) cooling to R. T.

distinguished on $5 \mathrm{Co} / \mathrm{Al} \mathrm{C} 400$ catalyst: one carbonate $\left(1780 \mathrm{~cm}^{-1}\right)$ formed via the interface oxygen [assigned as carbonate $\left._{(\mathrm{I})}\right]$ and three distinct bands $(1650,1445$ and $1230 \mathrm{~cm}^{-1}$ ) are other carbonates that formed on cobalt oxide surface [26]. The effect of the temperature up to $300{ }^{\circ} \mathrm{C}$ for the carbonates has been studied (figure 3(c)(h)). It is notice that the intensity of gaseous $\mathrm{CO}_{2}$ increases and the intensity of carbonates decreases with the temperature. Both types of carbonates can evolve $\mathrm{CO}_{2}$ as temperature above room temperature as equations of (2) and (4).

$$
*-\operatorname{carbonate}_{(\mathrm{I})} \rightarrow \mathrm{CO}_{2}+*_{(\mathrm{I})}
$$

where ${ }_{(I)}$ denotes the interface adsorption site. In the range of $\mathrm{RT}-75^{\circ} \mathrm{C}$, the equation (4) is preferential. As the temperature raise above $75^{\circ} \mathrm{C}$, the equation (2) is preferential. Comparison with $5 \mathrm{Co} / \mathrm{Si} \mathrm{C} 400$ catalyst, the re-adsorption of $\mathrm{CO}_{2}$ is not occurred at high temperatures (figure 3(c)-(i)) but re-adsorbs as the temperature back to room temperature on $5 \mathrm{Co} / \mathrm{Al} \mathrm{C} 400$ catalyst (figure 3(j)).
The spectra of $5 \mathrm{Co} / \mathrm{TiC} 400$ (figure 4) contained bands at $2349,2180,1618,1580,1420,1325$ and $1220 \mathrm{~cm}^{-1}$ between ambient temperature and $300{ }^{\circ} \mathrm{C}$. These can be assigned to gaseous $\mathrm{CO}_{2}\left(2349 \mathrm{~cm}^{-1}\right)$, linear adsorbed $\mathrm{CO}$ on $\mathrm{TiO}_{2}\left(2180 \mathrm{~cm}^{-1}\right)$ [27] and carbonates formed on cobalt oxide surface and/or carbonate-like species on the support $\left(1618,1580,1420,1325\right.$ and $\left.1220 \mathrm{~cm}^{-1}\right)$ [23], respectively. The variation of three supports is apparent. The adsorption of $\mathrm{CO}$ is not observed on both $\mathrm{SiO}_{2}$ and $\mathrm{Al}_{2} \mathrm{O}_{3}$ supports (figures 2 and 3 ), while a strong adsorption of $\mathrm{CO}$ on $\mathrm{TiO}_{2}\left(2180 \mathrm{~cm}^{-1}\right)$ is present at room temperature that is maintained after evacuation (figure 4(b)). According to the catalytic activity measurement (figure 1), the lower active of $5 \mathrm{Co} / \mathrm{Ti} \mathrm{C} 400$ may be ascribed to the strong adsorption of $\mathrm{CO}$ on $\mathrm{TiO}_{2}$ (assigned as $*_{\mathrm{s}}-\mathrm{CO}$ ). Not only the ${ }_{\mathrm{s}}-\mathrm{CO}$, but the formation of carbonate is observed simultaneously (figure 4(a)). As the temperature increased, the ${ }^{*}{ }_{\mathrm{r}} \mathrm{CO}$ migrates to the surface of cobalt oxide to form carbonates (figure 4(c)). The carbonates evolve $\mathrm{CO}_{2}$ as temperature further increased (figure $4(\mathrm{~d})-(\mathrm{h})$ ) above $50{ }^{\circ} \mathrm{C}$. The readsorption of $\mathrm{CO}_{2}$, is not observed at high temperatures or the temperature back to room temperature.

$$
*_{\mathrm{s}}-\mathrm{CO}+* \stackrel{T>R \cdot T .}{\longrightarrow} *-\text { carbonate }+*_{\mathrm{s}} \stackrel{T>50^{\circ} \mathrm{C}}{\longrightarrow} \mathrm{CO}_{2}+*
$$

where ${ }_{\mathrm{s}}$ denotes an adsorption site on $\mathrm{TiO}_{2}$.

The influence of $\mathrm{CO} / \mathrm{O}_{2}$ co-adsorption is studied on the $5 \mathrm{Co} / \mathrm{Si} \mathrm{C} 400,5 \mathrm{Co} / \mathrm{Al} \mathrm{C} 400$ and $5 \mathrm{Co} / \mathrm{Ti} \mathrm{C} 400$ samples. In the $\mathrm{CO} / \mathrm{O}_{2}$ adsorption experiments (figures 5-7), first 0.5 torr $\mathrm{CO}$ is adsorbed on the catalysts at room temperature giving rise to absorption bands (figures 24(a)), and then 0.5 torr $\mathrm{O}_{2}$ is introduced into the chamber (figures 5-7(a)).

Disappearance of weakly linear adsorbed $\mathrm{CO}$ on cobalt oxide and a significant band near $1427 \mathrm{~cm}^{-1}$ appears as $\mathrm{O}_{2}$ is introduced on $5 \mathrm{Co} / \mathrm{Si} \mathrm{C} 400$ sample (figure 5(a)) at room temperature. This indicates that the $\mathrm{CO}_{2}$ is formed immediately with the introduction of $\mathrm{O}_{2}$ over the $\mathrm{CO}$ pre-adsorbed on cobalt oxide. Also, the introduced $\mathrm{O}_{2}$ participates the irreversible $\mathrm{CO}$ adsorption (carbonates formation) that may be promoted the transformation of carbonates (i.e., from bidentate to monodentate carbonates). The new type carbonates is stable and increases with temperature up to $75{ }^{\circ} \mathrm{C}$ (figure 5(c)). As the temperature above $75^{\circ} \mathrm{C}$, the $\mathrm{CO}_{2}\left(2349 \mathrm{~cm}^{-1}\right)$ intensity significantly increases and the carbonates intensity decreases. This indicates that the activity of $5 \mathrm{Co} /$ Si C400 sample comes from the adsorbed $\mathrm{CO}$ and lattice oxygen of cobalt oxide, and part of $\mathrm{CO}_{2}$ formation via carbonates as equations (1) and (2). The consumed lattice oxygen $\left(*-\mathrm{O}_{\mathrm{L}}\right)$ may be restored through adsorption of oxygen molecules on the resulted vacancy $\left({ }_{\mathrm{L}}\right)$.

$$
2 *_{\mathrm{L}}+\mathrm{O}_{2} \rightarrow 2 *-\mathrm{O}_{\mathrm{L}}
$$




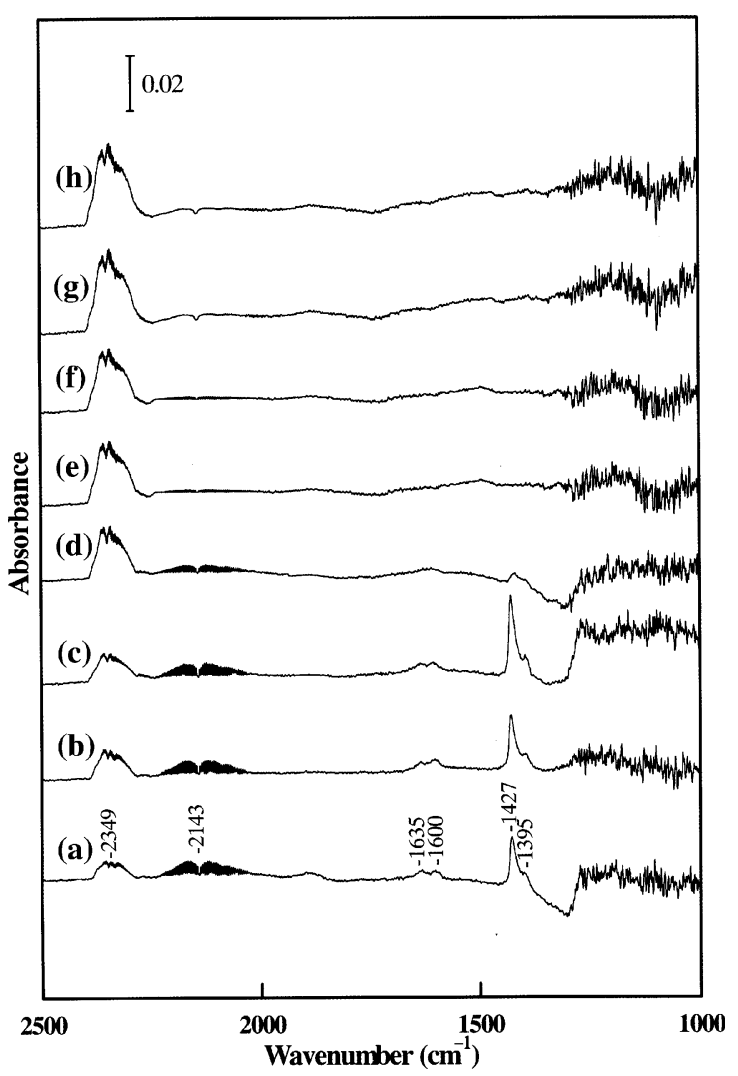

Figure 5. In situ FT-IR spectra of $5 \mathrm{Co} / \mathrm{SiC} 400$ sample after exposure to 0.5 torr $\mathrm{CO}$ and 0.5 torr $\mathrm{O}_{2}$ at various temperatures: (a) R. T.; (b) $50{ }^{\circ} \mathrm{C}$; (c) $75{ }^{\circ} \mathrm{C}$; (d) $100{ }^{\circ} \mathrm{C}$; (e) $150{ }^{\circ} \mathrm{C}$; (f) $200{ }^{\circ} \mathrm{C}$; (g) $250{ }^{\circ} \mathrm{C}$; (h) $300{ }^{\circ} \mathrm{C}$.

The spectrum of $\mathrm{CO} / \mathrm{O}_{2}$ co-adsorption (figure $6(\mathrm{a})$ ) is similar to $\mathrm{CO}$ adsorption on $5 \mathrm{Co} / \mathrm{Al} \mathrm{C} 400$ given in (figure 3(a)). As $\mathrm{O}_{2}$ is introduced and temperature is elevated, there is no obvious band changed (figure 6(b)(h)). It means that the $\mathrm{CO}$ oxidation on $5 \mathrm{Co} / \mathrm{Al} \mathrm{C} 400$ sample comes from the evolved of $\mathrm{CO}_{2}$ on both types of carbonates as temperature above room temperature as equations of (2) and (4).

Figure 7 shows the spectrum of $\mathrm{CO} / \mathrm{O}_{2}$ co-adsorption on $5 \mathrm{Co} / \mathrm{Ti} \mathrm{C} 400$ at various temperatures. The $\mathrm{CO}_{2}$ adsorption on cobalt oxide $\left(2350 \mathrm{~cm}^{-1}\right)$ is observed at room temperature [24]. The intensity of adsorbed $\mathrm{CO}_{2}$ is decreased with raising temperature and disappears above $100{ }^{\circ} \mathrm{C}$ (figure $7(\mathrm{a})-(\mathrm{c})$ ).

$$
*+\mathrm{CO}_{2}+\stackrel{T<100^{\circ} \mathrm{C}}{\longrightarrow} *-\mathrm{CO}_{2} \stackrel{T>100^{\circ} \mathrm{C}}{\longrightarrow} *+\mathrm{CO}_{2}
$$

According to the catalytic activity measurement (figure 1), the less active of $5 \mathrm{Co} / \mathrm{Ti} \mathrm{C} 400$ and decreasing of activity with raising temperature up to $100{ }^{\circ} \mathrm{C}$ may be ascribed to both strong adsorption of $\mathrm{CO}$ on $\mathrm{TiO}_{2}$ and $\mathrm{CO}_{2}$ on cobalt oxide. As the temperature above $100{ }^{\circ} \mathrm{C}$, not only the ${ }_{\mathrm{s}}-\mathrm{CO}$ migrates to the surface of cobalt oxide to form carbonates but the desorbed of $*-\mathrm{CO}_{2}$ is stimulated.

Accordingly, three different models of $\mathrm{CO}$ adsorbed and $\mathrm{CO}_{2}$ desorbed over supported cobalt catalysts are

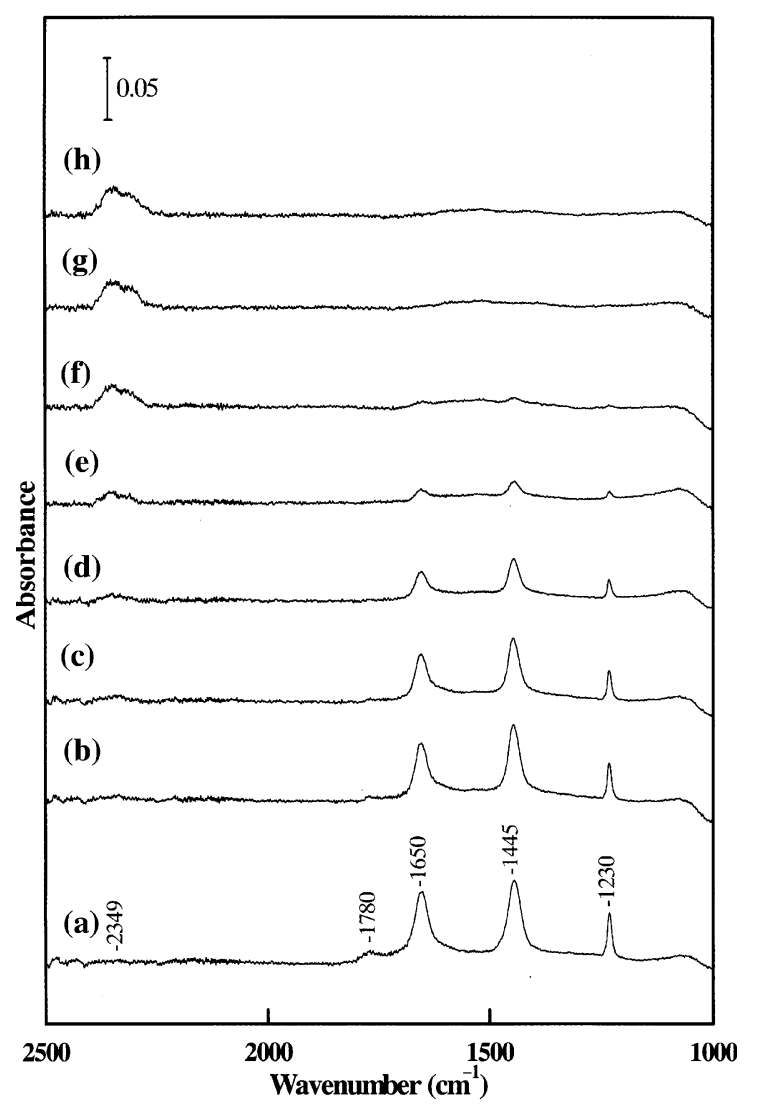

Figure 6. In situ FT-IR spectra of 5Co/Al C400 sample after exposure to 0.5 torr $\mathrm{CO}$ and 0.5 torr $\mathrm{O}_{2}$ at various temperatures: (a) R. T.; (b) $50{ }^{\circ} \mathrm{C}$; (c) $75{ }^{\circ} \mathrm{C}$; (d) $100{ }^{\circ} \mathrm{C}$; (e) $150{ }^{\circ} \mathrm{C}$; (f) $200{ }^{\circ} \mathrm{C}$; (g) $250{ }^{\circ} \mathrm{C}$; (h) $300{ }^{\circ} \mathrm{C}$.

assigned in figure 8 . The major adsorbed species is listed in table 1. Excepting the carbonates formation, the $\mathrm{CO}$ adsorbed on $5 \mathrm{Co} / \mathrm{Si} \mathrm{C} 400$ sample (figure $8(a)$ ) to promote the $\mathrm{CO}$ oxidation. The activity comes from the adsorbed $\mathrm{CO}$ and lattice oxygen of cobalt oxide, and part of $\mathrm{CO}_{2}$ formation via carbonates as equations (1) and (2). Both types of carbonates are formed on $5 \mathrm{Co} / \mathrm{Al}$ C400 sample (figure $8(\mathrm{~b})$ ) to promote the $\mathrm{CO}$ oxidation. The activity comes from the evolved of $\mathrm{CO}_{2}$ on both types of carbonates as temperature above room temperature as equations of (2) and (4). The less active of $5 \mathrm{Co} / \mathrm{Ti} \mathrm{C} 400$ sample can be ascribed to both strong adsorption of $\mathrm{CO}$ on $\mathrm{TiO}_{2}$ and $\mathrm{CO}_{2}$ on cobalt oxide (figure 8(c)).

\section{Conclusion}

Based on the $\mathrm{CO}$ catalytic oxidation activities and adsorption studies by in situ FT-IR over supported cobalt catalysts, we propose

1. The activity of $5 \mathrm{Co} / \mathrm{Si} \mathrm{C} 400$ sample comes from the adsorbed $\mathrm{CO}$ and lattice oxygen of cobalt oxide, and part of $\mathrm{CO}_{2}$ formation via carbonates. 


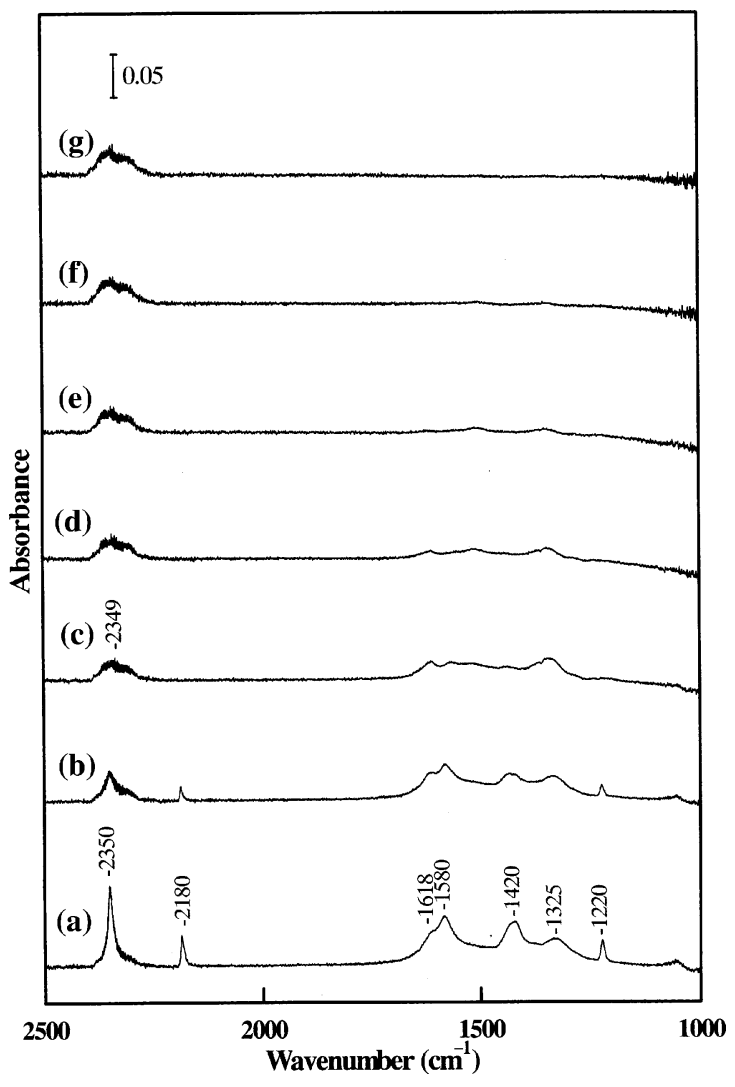

Figure 7. In situ FT-IR spectra of $5 \mathrm{Co} / \mathrm{Ti} \mathrm{C} 400$ sample after exposure to 0.5 torr $\mathrm{CO}$ and 0.5 torr $\mathrm{O}_{2}$ at various temperatures: (a) R. T.; (b) $50{ }^{\circ} \mathrm{C}$; (c) $100{ }^{\circ} \mathrm{C}$; (d) $150{ }^{\circ} \mathrm{C}$; (e) $200{ }^{\circ} \mathrm{C}$; (f) $250{ }^{\circ} \mathrm{C}$; (g) $300{ }^{\circ} \mathrm{C}$.

2. The activity of $5 \mathrm{Co} / \mathrm{Al} \mathrm{C} 400$ sample comes from the evolved of $\mathrm{CO}_{2}$ on both types of carbonates.

3. The less active of $5 \mathrm{Co} / \mathrm{Ti} \mathrm{C} 400$ sample can be ascribed to both strong adsorption of $\mathrm{CO}$ on $\mathrm{TiO}_{2}$ and $\mathrm{CO}_{2}$ on cobalt oxide.

Table 1

Types of adsorbed species over supported cobalt catalysts

\begin{tabular}{lccccc}
\hline Catalysts & \multicolumn{5}{c}{ Adsorbed species $\left(\mathrm{cm}^{-1}\right)$} \\
\cline { 2 - 6 } & ${ }^{*}-\mathrm{CO}^{\mathrm{a}}$ & $*{ }_{\mathrm{s}}-\mathrm{CO}^{\mathrm{b}}$ & ${ }_{\mathrm{s}}-\mathrm{CO}_{2}{ }^{\mathrm{c}}{ }^{*}{ }_{-}$Carbonate $_{(\mathrm{I})}{ }^{\mathrm{d}}$ & $*-$ Carbonates \\
\hline $5 \mathrm{Co} / \mathrm{Si} \mathrm{C} 400$ & 2166 & - & - & - & $1610,1427,1395$ \\
$5 \mathrm{Co} / \mathrm{Al} \mathrm{C} 400$ & - & - & - & 1780 & $1650,1445,1230$ \\
$5 \mathrm{Co} / \mathrm{Ti} 07400$ & - & 2180 & 2350 & - & $1420,1325,1220$ \\
\hline
\end{tabular}

${ }^{\text {a }}$ Linear $\mathrm{CO}$ adsorbed on cobalt oxide.

${ }^{\mathrm{b}} \mathrm{CO}$ adsorbed on $\mathrm{TiO}_{2}$.

${ }^{\mathrm{c}} \mathrm{CO}_{2}$ adsorbed on cobalt oxide.

${ }^{\mathrm{d}}$ Interface oxygen to form carbonate.

\section{Acknowledgements}

We are pleased to acknowledge the financial support for this study by the National Science Council of the Republic of China under contract number NSC 932113-M-014-003.
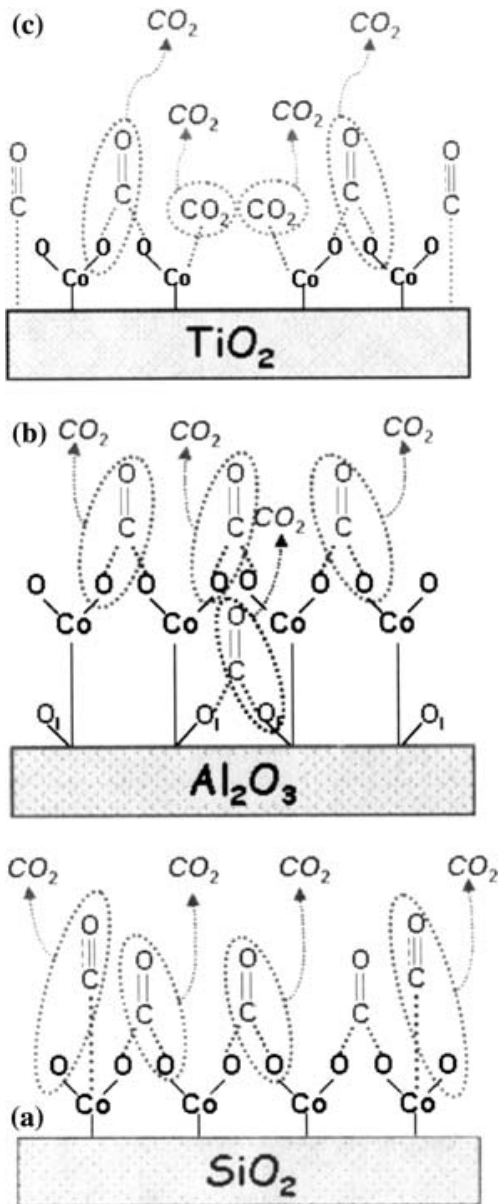

Figure 8. Proposed models of $\mathrm{CO}$ adsorbed and $\mathrm{CO}_{2}$ desorbed over supported cobalt catalysts: (a) $5 \mathrm{Co} / \mathrm{Si} \mathrm{C} 400$; (b) $5 \mathrm{Co} / \mathrm{Al} \mathrm{C} 400$; (c) $5 \mathrm{Co} / \mathrm{Ti} \mathrm{C} 400$.

\section{References}

[1] G. Glaspell, L. Fuoco and M.S. El-Shall, J. Phys. Chem. B 109 (2005) 17351.

[2] U. Oran and D. Uner, Appl. Catal. B54 (2004) 183.

[3] M. Faticanti, N. Cioffi, S.D. Rossi, N. Ditaranto, P. Porta, L. Sabbatini and T.B. Zacheo, Appl. Catal. B60 (2005) 73.

[4] P. Bera, A. Gayen, M.S. Hegde, N.P. Lalla, L. Spadaro, F. Frusteri and F. Arena, J. Phys. Chem. B 107 (2003) 6122.

[5] T. Visser, T.A. Nijhuis, A.M.J. van der Eerden, K. Jenken, Y. Ji, W. Bras, S. Nikitenko, Y. Ikeda, M. Lepage and B.M. Weckhuysen, J. Phys. Chem. B 109 (2005) 3822.

[6] T. Maillet, C. Solleau, J. Barbier Jr. and D. Duprez, Applied Catal. B 14 (1997) 85.

[7] E. Bekyarova, P. Fornasiero, J. Kašpar and M. Graziani, Catal. Today 45 (1998) 179.

[8] D.G. Castner, Ph.R. Watson and I.Y. Chan, J. Phys. Chem. 93 (1989) 3188.

[9] D.A.H. Cunningham, T. Kobayashi, N. Kamijo and M. Haruta, Catal. Lett. 25 (1994) 257.

[10] Y.M. Kang and B.Z. Wan, Catal. Today 26 (1995) 59.

[11] Y.J. Mergler, A. van Aalst, J. van Delft and B.E. Nieuwenhuys, Appl. Catal. B 10 (1996) 245.

[12] Y.J. Mergler, J. Hoebink and B.E. Nieuwenhuys, J. Catal. 167 (1997) 305. 
[13] P. Thormählen, M. Skoglundh, E. Fridell and B. Andersson, J. Catal. 188 (1999) 300.

[14] J. Jansson, J. Catal. 194 (2000) 55.

[15] M. Kang, M.W. Song and C.H. Lee, Appl. Catal. A 251 (2003) 143.

[16] H.K. Lin, H.C. Chiu, H.C. Tsai, S.H. Chien and C.B. Wang, Catal. Lett. 88 (2003) 169.

[17] H.K. Lin, C.B. Wang, H.C. Chiu and S.H. Chien, Catal. Lett. 86 (2003) 63.

[18] C.B. Wang, C.W. Tang, S.J. Gau and S.H. Chien, Catal. Lett. 101 (2005) 59.

[19] V.D. Sokolovskii, G.K. Boreskov, A.A. Davydov and Yu.M. Shchekochikhin, Dokl. Akad. Nauk SSSR 214 (1974) 1361

[20] A.A. Davydov, "IK spektroskopiya v khimii poverkhnosti oksidov (IR spectroscopy in the surface chemistry of oxides)", Nauka, Novosibirsk (1984) p. 242 (in Russian).
[21] Yu.A. Lokhov, V.A. Sadykov, S.F. Tikhov, G.M. Kryukova, M.N. Bredikhin, V.V. Popovskii, N.N. Bulgakov, V.A. Razdobarov, L.P. Soloveva and I.P. Olenkova, Proc. 6th Int. Symp. Heterogen. Catalysis, Sofia, (1987) Part 1, p. 359.

[22] J. Jansson, A.E.C. Palmqvist, E. Fridell, M. Skoglundh, L. Österlund, P. Thormählen and V. Langer, J. Catal. 211 (2002) 387.

[23] P. Konova, A. Naydenov, Cv. Venkov, D. Mehandjiev, D. Andreeva and T. Tabakova, J. Mol. Catal. A 213 (2004) 235.

[24] Y.A. Lokhov, S.F. Tikhov, M.N. Bredikhin, A.G. Zhirnyagin and V.A. Sadykov, Mendeleev Comm. (1992) 10.

[25] E. Finocchio, G. Busca, V. Lorenzelli and V.S. Escribano, J. Chem. Soc. Faraday Trans. 92 (1996) 1587.

[26] A.A. Davydov, "Infrared spectroscopy of adsorbed species on the surface of transition metal oxides", New York (1984) p. 38.

[27] K.I. Hadjiivaniov and G.N. Vayssilov, Adv. Catal. 47 (2002) 307. 